DOI: $10.4274 /$ gulhane.galenos.2020.1076

Gulhane Med J 2020;62:213-23

\title{
Osteoradionecrosis - a review of clinical features and management
}

\section{(1) Vidya Ajila, (1) Shruthi Hegde}

Nitte (Deemed to be University), AB Shetty Memorial Institute of Dental Sciences (ABSMIDS), Department of Oral Medicine and Radiology, Mangalore, India

\section{Date submitted:}

04.04.2020

Date accepted:

16.04.2020

Online publication date: 15.12.2020

\section{Corresponding Author:}

Vidya Ajila MDS, Nitte (Deemed to be University), AB Shetty Memorial Institute of Dental Sciences

(ABSMIDS), Department of Oral Medicine and Radiology, Mangalore, India

ajila_v@yahoo.com

ORCID:

orcid.org/0000-0002-5744-9322

Keywords: Osteoradionecrosis, mandible, radiotherapy

\begin{abstract}
Radiotherapy is an important part of oral cancer management. A significant complication of radiotherapy to the head and neck is osteoradionecrosis (ORN). The present report reviews the risk factors, clinical features, and management of ORN affecting the maxilla and mandible. A "PubMed" database search was done to identify "case reports" of ORN that were published, using the keywords "osteoradionecrosis", "jaw",' "mandible" and "maxilla". Data on ORN published within the past 10 years from 2008 to 2018 were collected and analyzed. A total of 23 full text articles reporting 27 cases of ORN were identified. Males constituted $84 \%$ of the cases. The mandible was affected in $96 \%$ of cases with bilateral involvement in $26.9 \%$ of cases and posterior mandibular involvement in $53.8 \%$ of cases. The amount of radiation received ranged from 50 Gy to $77 \mathrm{~Gy}$. ORN occurred in 3.87 years on average after radiotherapy. The highest risk of developing ORN was associated with extraction of mandibular teeth within the radiation field in patients who received a radiation dose greater than $60 \mathrm{~Gy}$. ORN was managed using varied methods such as surgical therapy, reconstruction with free fibular graft, low level laser therapy, and platelet rich gel. The recurrence of ORN was reported in $22 \%$ cases ranging from three weeks to one year later. In conclusion, the present review highlights the clinical features and risk factors associated as well as the various methods used in the treatment of ORN. The use of preventive strategies and advanced methods of management can decrease the incidence of ORN.
\end{abstract}

\section{Introduction}

Osteoradionecrosis (ORN) is a severe complication of external beam radiotherapy (RT) for malignancies affecting the head and neck $(1,2)$. It is defined as 'A potentially severe, delayed radiation-induced injury, characterized by bone tissue necrosis, failure to heal, and exposed bone for at least three months' (3). The incidence of ORN in the head and neck region varies from $2 \%$ to $22 \%$ in subjects with a history of radiotherapy (3).

Various mechanisms have been proposed to explain the occurrence of ORN. These include the most commonly accepted hypoxic-hypocellular-hypovascular concept where radiation causes hypoxia of the bone, death of bone cells and long term damage to vascular supply as a result of endothelial cell damage ultimately leading to bone death
(4). Another theory suggests that radiotherapy results in decreased soft tissue matrix which gets replaced with fibrous tissue, thereby increasing the tendency to develop ORN (5). Another suggested cause is the suppression of osteoclast related bone turnover. Some authors have proposed that radiation leads to a local inflammatory process which causes osteoblastic cell death, thereby preventing the repopulation of cells (6). The most recent theory of ORN is the fibroatrophic theory. According to this theory, vascular changes in the bone lead to endothelial changes along with an inflammatory response. This is followed by abnormal fibroblastic activity and altered bone healing which is more susceptible to infection (6).

Among the various classifications, the one given by Notani et al. (7), which is based on the amount of bone involvement, is 
simple and preferred by many authors (8). ORN is a progressive condition which is difficult to treat. Various management strategies include sequestrectomy, resection, segmental mandibulectomy, and hyperbaric oxygen (HBO) therapy with varied results. Recent methods include the use of Pentoxifylline, Tocopherol and Clodronate, "PENTOCLO" (8).

The present report reviewed the current literature of the demographic characters, clinical features, and latest management techniques employed in the treatment of ORN.

A "PubMed" database search was done to identify case reports on ORN, published using the keywords "osteoradionecrosis", "jaw", "mandible", and "maxilla". Data on ORN published within the past 10 years from 2008 to 2018 were collected and analyzed. Only those case reports for which full text was available were considered in the review. Demographic characters, clinical features, and management were tabulated. Descriptive statistics were calculated using means and percentages.

A total of 23 full text articles reporting 27 cases of ORN were identified. The age range of the subjects was from 18 years to 84 years with a mean of 49 years. Males constituted $84 \%$ of the cases while females accounted for $16 \%$. In $96 \%$ of the cases, the mandible was affected while $4 \%$ involved both the maxilla and mandible. The right and left mandible were equally affected in $34.6 \%$ of cases; and ORN was present bilaterally in $26.9 \%$ of cases. The posterior mandible was the most common site in $53.8 \%$ of cases.

ORN occurred three months -13 years later following radiotherapy, with an average time of 3.87 years. Associated malignancies varied with maximum cases having received radiotherapy for tonsillar carcinoma (Figure 1).

Radiotherapy was the primary treatment given in $25.9 \%$ of cases; surgery and radiotherapy were given in $40.7 \%$ of cases; subjects received adjuvant chemotherapy in $25.9 \%$ of cases while a combination of surgery, chemotherapy and radiotherapy was given in $7.4 \%$ of cases (Figure 2).

The amount of radiation received ranged from 50 Gy to 77 Gy.

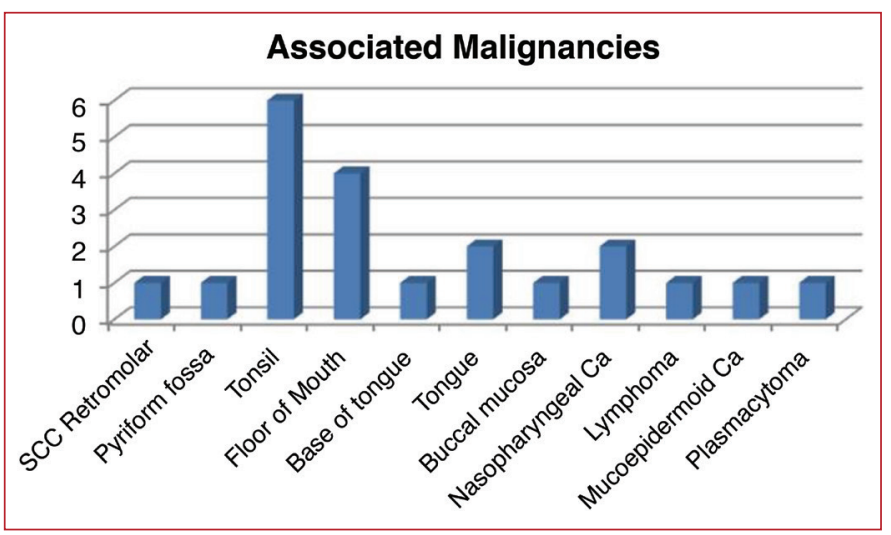

Figure 1. Graph showing the site of reported malignancies SCC: Squamous cell carcinoma, Ca: Carcinoma
The presenting features of ORN included pain and discharge in $25.9 \%$ of cases, pathological fracture in $14.8 \%$ of cases, dysphagia and swelling in $7.4 \%$ of cases and anesthesia of the inferior alveolar nerve in $7.4 \%$ of cases.

Risk factors for ORN were tooth extraction, tobacco and alcohol abuse, and underlying medical conditions.

Management included surgical resection with fibular graft in $37 \%$ of cases, HBO therapy in $29.6 \%$ of cases, and segmental resection in $18.5 \%$ of cases. Other methods of ORN management included the use of leukocyte platelet-rich plasma (PRP), sequestrectomy, surgical debridement with Integra skin regeneration system and vacuum-assisted closure (VAC) system.

Recurrence of ORN was reported in $22 \%$ of cases, which ranged from three weeks to one year later. Table $1(6,9-27)$ summarizes the details of subjects with ORN as reported by the various authors.

\section{Discussion}

Regaud first described post radiation ORN of the jaw in 1922 (13). Ewing, in 1926, reported the bone changes after radiotherapy as radiation osteitis (11).

Early bone changes after radiotherapy includes hyperemia, endarteritis, and cell death, while late changes include thrombosis, hypovascularization, and fibrosis (5).

ORN is a late effect of radiotherapy. RT for cancer in the head and neck has an increased chance of causing mandibular ORN. Recent reports suggest that the incidence of ORN has decreased from $20 \%$ to around $4-8 \%$. This decrease is related to the elimination of all risk factors prior to radiotherapy and

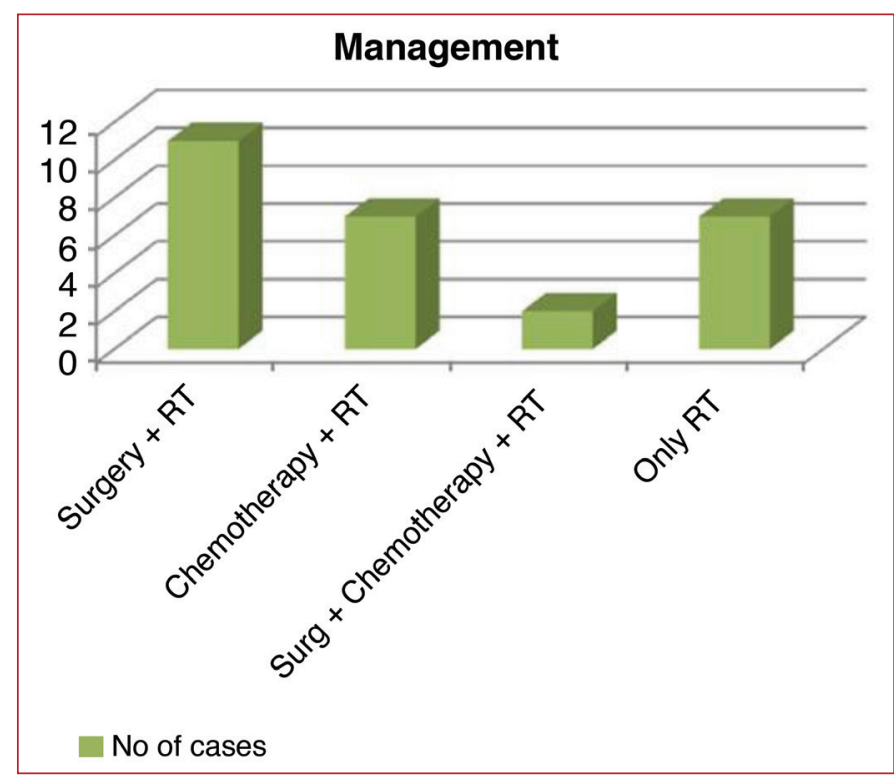

Figure 2. Graph showing the management strategies used in the reported cases RT: Radiotherapy 
recent advances in radiotherapy such as intensity modulated radiotherapy (IMRT) (28). The incidence of occurrence of ORN in the mandible is between $2 \%$ and $22 \%$ with most cases occurring in the mandibular body (9). This is in accordance with the present report where the mandible was the most affected, predominantly the posterior mandible. This increased predilection for the mandible is due to the richer vascularity in the maxilla and also because the mandible is irradiated more often. Also, since the mandibular bone is denser, the amount of radiation absorbed by the bone is more $(6,29)$.

Around $70-90 \%$ of ORN cases are reported to occur within the first three years after radiotherapy. In the present report, ORN occurred from three months to 13 years following radiotherapy. However, the majority of cases occurred within the first five years. This variability could be because of the size and nature of the tumor, the type of radiotherapy used or individual patient risk factors (28).

The amount of radiation received ranged from 50 Gy to 77 Gy. The risk of developing ORN is medium at a radiation dosage of 40-60 Gy and high at a dose above 60 Gy (23). This is in conformity with our results.

The subjects may be asymptomatic in the initial stages. The main diagnostic feature is the presence of exposed bone in the mucosa or skin which can get secondarily infected. Other features include pain, dysesthesia, halitosis, and dysgeusia. Severe cases may lead to fistula formation from the oral mucosa or skin and pathological fractures (9). Diagnosis of ORN is made on the basis of patient history and the presence of exposed bone for more than three months. Radiological investigations such as panoramic radiographs and computed tomography are used to assess the extent of bone changes $(17,23,30)$. This is similar to the clinical features reported by ORN cases in the present review.

Chemoradiotherapy (CRT) is linked to better locoregional control and overall survival and eradicates micrometastases. Although CRT is associated with an increase in early toxicity such as mucositis, the role of CRT in late toxicity is not clear. Recent studies have concluded that CRT does not increase the risk of ORN. In the present review, $25.9 \%$ of the cases received CRT. However, previous studies show difference in the incidence of ORN after RT and CRT (31).

Conventional management of ORN includes surgical debridement, sequestrectomy, oral hygiene maintenance with oral antiseptics, and the use of medications such as analgesics, antibiotics and corticosteroids (11). Segmental mandibulectomy is the next option followed by a complex reconstruction. In accordance with the fibro atrophic theory, a recent regimen for ORN recommends the use of vascular directed therapy using alpha - tocopherol (Vitamin E) and pentoxifylline (PENTO). Addition of clodronate to PENTO was found to be beneficial but carried the risk of bisphosphonate induced osteonecrosis
$(9,26)$. Delanian et al. $(30,32)$ reported that PENTOCLO resulted in spontaneous sequestrectomy within the first six months of therapy leading to bone healing. PENTOCLO is not recommended in patients with recurrent or residual tumor. HBO therapy has been used along with surgery due to its ability to promote vascularity. HBO therapy includes the use of $100 \%$ oxygen for 90 mins at 2.4 atm pressure (24). However, recent trials have failed to demonstrate definite benefits. HBO is advised as an adjunct when resection or reconstruction surgery is needed (26). In the present report, HBO therapy was used in $29.6 \%$ of cases, usually in association with surgical debridement and resection with good results.

ORN can be of two types-spontaneously occurring and trauma induced (5). Spontaneously occurring ORN depends on the radiation dose that is received while ORN after dental treatments is categorized as trauma-induced ORN $(5,27)$. Around $5 \%$ of cases occur following dental extraction (8). This is reflected in the present results where only two cases of ORN were reported after tooth extraction.

Spontaneous ORN commonly occurs between 6 months and 2 years after radiotherapy while the possibility of traumainduced ORN is for long term. Thus, the risk of trauma induced ORN is higher in the dentate subjects due to extraction or dental and periodontal infection (9). Other factors include the grade and site of tumor, amount of radiation, immune deficiencies and any comorbidities (14). Moon et al. (28) found that preradiotherapy extractions were an independent risk factor for ORN but mentioned that it might be a reflection of the poor oral hygiene of the subjects. The use of IMRT has decreased the incidence of ORN especially in combination with good oral hygiene measures and decreased radiation to the mandible and parotid salivary glands (8). Contributing factors noted in the present review included tobacco and alcohol abuse and underlying medical conditions.

Marx's staging of ORN as stage 1, stage 2 and stage 3 is still widely followed (21). Stage 3 ORN requires surgical intervention (23). Kraeima et al. (23) used a novel method of combining the chemotherapy with the radiotherapy isodose curves in order to accurately predict the areas of ORN risk, and plan exact resection of affected bone and screw locations for reconstruction plates which are outside high dose areas.

Management of ORN in the present review was done using various methods. Most management strategies involved surgical treatment with the debridement of nonviable tissue and subsequent reconstruction. Successful management strategies included the use of allogeneic platelet gel (1) and skin regeneration systems for the repair of minor to moderate intraoral defects (3). Schepers et al. (10) described successful prosthetic rehabilitation with fibular graft using virtual implant planning. PRP was used to regain mandibular integrity and continuity of bone following 


\begin{tabular}{|c|c|c|c|c|c|c|}
\hline Authors & Site of ORN & $\begin{array}{l}\text { Associated } \\
\text { malignancy with } \\
\text { staging }\end{array}$ & RT cycles & $\begin{array}{l}\text { Any other } \\
\text { concurrent } \\
\text { therapy }\end{array}$ & $\begin{array}{l}\text { Agel } \\
\text { Sex }\end{array}$ & $\begin{array}{l}\text { Duration } \\
\text { after RT }\end{array}$ \\
\hline $\begin{array}{l}\text { Curi et al. (5) } \\
2017\end{array}$ & $\begin{array}{l}\text { Bilateral posterior } \\
\text { mandible }\end{array}$ & $\begin{array}{l}\text { Retromolar } \\
\text { trigone Ca (T2 } \\
\text { N2 M0) }\end{array}$ & $\begin{array}{l}\text { Postoperative } \\
\text { fractionated RT } \\
\text { (5 fractions/week; } \\
2.0 \text { Gy/fraction; } 34 \\
\text { sessions total of } 68 \\
\text { Gy) }\end{array}$ & $\begin{array}{l}\text { Surgery right } \\
\text { radical neck } \\
\text { dissection (lymph } \\
\text { nodes levels } 2 \text { to } 4 \text { ) } \\
\text { without ligation of } \\
\text { the external carotid } \\
\text { artery }\end{array}$ & $56 / \mathrm{M}$ & $8 \mathrm{yrs}$ \\
\hline $\begin{array}{l}\text { Piccin et al. (1) } \\
2016\end{array}$ & $\begin{array}{l}\text { Right posterior } \\
\text { mandible }\end{array}$ & $\begin{array}{l}\text { Right piriform } \\
\text { sinus poorly } \\
\text { differentiated } \\
\text { adenocarcinoma }\end{array}$ & $\begin{array}{l}\text { RT } 7,000 \text { cGy were } \\
\text { given over } 35 \text { sessions }\end{array}$ & $\begin{array}{l}\text { Chemotherapy } \\
\text { (cisplatin } 100 \mathrm{mg} / \\
\mathrm{m}^{2} \text { intravenous) }\end{array}$ & $61 / \mathrm{M}$ & $9 \mathrm{yrs}$ \\
\hline $\begin{array}{l}\text { Beech and } \\
\text { Farrier (3) } 2016\end{array}$ & $\begin{array}{l}\text { Right posterior } \\
\text { mandible }\end{array}$ & $\begin{array}{l}\text { Left-sided } \\
\text { tonsillar } \\
\text { carcinoma }\end{array}$ & RT & Surgical excision & $54 / \mathrm{M}$ & $5 \mathrm{yrs}$ \\
\hline $\begin{array}{l}\text { Schepers et al. } \\
\text { (10) } 2013\end{array}$ & $\begin{array}{l}\text { Right anterior } \\
\text { mandible }\end{array}$ & $\begin{array}{l}\text { Squamous cell } \\
\text { carcinoma of the } \\
\text { anterior floor of } \\
\text { the mouth }\end{array}$ & RT 66 Gy & Surgical excision & $54 / \mathrm{M}$ & $1 \mathrm{yr}$ \\
\hline $\begin{array}{l}\text { Reiffel et al. (11) } \\
2012\end{array}$ & $\begin{array}{l}\text { Left posterior } \\
\text { mandible }\end{array}$ & $\begin{array}{l}\text { Cancer of base } \\
\text { of tongue stage } 4\end{array}$ & RT & Chemotherapy & $55 / \mathrm{M}$ & $2.5 \mathrm{yrs}$ \\
\hline $\begin{array}{l}\text { Rao et al. (4) } \\
2012\end{array}$ & $\begin{array}{l}\text { Right posterior } \\
\text { mandible }\end{array}$ & $\begin{array}{l}\text { Low grade } \\
\text { mucoepidermoid } \\
\text { carcinoma }\end{array}$ & RT & Surgical excision & $38 / F$ & 5 yrs \\
\hline $\begin{array}{l}\text { Poglio et al. (12) } \\
2011\end{array}$ & $\begin{array}{l}\text { Right posterior } \\
\text { mandible }\end{array}$ & Unknown & RT & & $41 / \mathrm{M}$ & 2 yrs \\
\hline $\begin{array}{l}\text { Man et al. (13) } \\
2015\end{array}$ & $\begin{array}{l}\text { Right posterior } \\
\text { mandible }\end{array}$ & $\begin{array}{l}\text { Malignant } \\
\text { lymphoma }\end{array}$ & RT 60 Gy & Chemotherapy & 18/M & $1 \mathrm{yr}$ \\
\hline $\begin{array}{l}\text { Scala et al. (14) } \\
2010\end{array}$ & $\begin{array}{l}\text { Bilateral anterior } \\
\text { and posterior } \\
\text { mandible }\end{array}$ & $\begin{array}{l}\text { Squamous cell } \\
\text { carcinoma of the } \\
\text { left half of tongue } \\
\text { PT1pN0 }\end{array}$ & $\begin{array}{l}\text { RT } 33 \text { visits, } 5 \text { visits } \\
\text { per week; each } \\
\text { consisted of a dose of } \\
200 \text { cGy with a total } \\
\text { dose of } 6,600 \text { cGy with } \\
\text { Lonidamine }\end{array}$ & $\begin{array}{l}\text { Partial left } \\
\text { glossectomy with } \\
\text { conservative neck } \\
\text { dissection (CND) } \\
\text { and bilateral } \\
\text { suprahyoid lymph } \\
\text { node dissection }\end{array}$ & $44 / \mathrm{M}$ & 4 yrs \\
\hline $\begin{array}{l}\text { Khatami et al. } \\
\text { (15) } 2010\end{array}$ & $\begin{array}{l}\text { Bilateral anterior } \\
\text { and posterior } \\
\text { mandible }\end{array}$ & $\begin{array}{l}\text { Cancer of } \\
\text { unknown primary }\end{array}$ & RT & & $62 / \mathrm{M}$ & \\
\hline
\end{tabular}


Clinical features

Dysphagia caused by a painful, swollen, and discolored tongue
Management

Hyperbaric oxygen therapy (30

sessions: 20 sessions before surgery

and 10 sessions after surgery; 2.4

ATA; 90-minute session in a

monoplace chamber. Bilateral

marginal bone resections
Any other

Associated tongue

necrosis
Risk factor

Tooth extraction

under local anesthesia using

vasoconstrictor
Severe dysphagia, fever $>38^{\circ} \mathrm{C}$, rigor swelling of the right jaw and right sternocleidomastoid muscle

Pain, difficulty eating, foul taste. Anesthesia of right inferior dental nerve; pathological fracture

Oral dehiscence and necrotic mandibular bone

\section{Necrotic left mandibular body}

Pain, restricted mouth opening and discharge from ear; discoloration of overlying skin

Lower jaw defect involving the oral mucosa, mandibular bone, external skin, and soft tissue, communication between the oral cavity and the exterior
Leukocyte platelet-rich plasma (PRP) every 3 days for a total of 7 weeks (22 applications in total)
Alcohol abuse

\section{Surgical debridement and Integra skin regeneration system}

\section{Surgical resection followed by}

reconstruction with a free

osseous flap with the planning of an

implant-based prosthesis

\section{Segmental mandibulectomy followed}

by free fibular graft

Hyperbaric oxygen therapy

\section{Mastoiditis}

Subtotal mandibulectomy, fibular graft and vacuum-assisted closure system
Stomatitis, purulent abscesses and exposed alveolar process $\mathrm{H} / \mathrm{o}$ tooth exfoliation
Moxifloxacin hydrochloride $600 \mathrm{mg}$ daily dose for 20 days, regenerative surgery with autologous platelet rich plasma
Recurrent ORN 2 yrs later repaired using stereolithographic 3-Dimensional Printing modeling technology osteomyocutaneous flap 


\begin{tabular}{|c|c|c|c|c|c|c|}
\hline Authors & Site of ORN & $\begin{array}{l}\text { Associated } \\
\text { malignancy with } \\
\text { staging }\end{array}$ & RT cycles & $\begin{array}{l}\text { Any other } \\
\text { concurrent } \\
\text { therapy }\end{array}$ & $\begin{array}{l}\text { Agel } \\
\text { Sex }\end{array}$ & $\begin{array}{l}\text { Duration } \\
\text { after RT }\end{array}$ \\
\hline $\begin{array}{l}\text { Mendonça and } \\
\text { Juiz-Lopez (16) } \\
2010\end{array}$ & $\begin{array}{l}\text { Mandibular } \\
\text { and maxillary } \\
\text { anterior and } \\
\text { posterior }\end{array}$ & Tonsillar cancer & RT & & $63 / \mathrm{M}$ & \\
\hline $\begin{array}{l}\text { Pautke et al. } \\
\text { (17) } 2010\end{array}$ & $\begin{array}{l}\text { Right anterior and } \\
\text { posterior mandible }\end{array}$ & $\begin{array}{l}\text { Extramedullary } \\
\text { plasmocytoma }\end{array}$ & RT chest at 50 Gy & $\begin{array}{l}\text { Adenectomy and } \\
\text { lobectomy of the } \\
\text { right lower lobe } \\
\text { Bisphosphonate } \\
\text { therapy }\end{array}$ & $72 / \mathrm{M}$ & $11 \mathrm{yrs}$ \\
\hline $\begin{array}{l}\text { Pautke et al. } \\
\text { (17) } 2010\end{array}$ & $\begin{array}{l}\text { Left anterior and } \\
\text { posterior mandible }\end{array}$ & $\begin{array}{l}\text { Carcinoma of the } \\
\text { left margin of the } \\
\text { tongue pT1, pN1, } \\
\text { Mx }\end{array}$ & $\begin{array}{l}\text { RT } 68.7 \text { Gy; } \\
\text { brachytherapy } 62.5 \mathrm{~Gy} \\
9 \text { yrs later }\end{array}$ & $\begin{array}{l}\text { Bilateral neck } \\
\text { dissection and } \\
\text { partial glossectomy; } \\
\text { chemotherapy } \\
\text { (cisplatin and } \\
5 \text {-fluorouracil) } 9 \text { yrs } \\
\text { later }\end{array}$ & $68 / \mathrm{M}$ & $11 \mathrm{yrs}$ \\
\hline $\begin{array}{l}\text { Le Stanc et al. } \\
\text { (18) } 2009\end{array}$ & $\begin{array}{l}\text { Left posterior } \\
\text { mandible }\end{array}$ & $\begin{array}{l}\text { Left tonsil } \\
\text { squamous } \\
\text { cell carcinoma } \\
\text { extending to } \\
\text { tongue and skull } \\
\text { base cT4N1M0 }\end{array}$ & RT 70 Gy & $\begin{array}{l}\text { Chemotherapy } \\
\text { (Carboplatin- } \\
\text { Paclitaxel) }\end{array}$ & $48 / \mathrm{M}$ & $2 \mathrm{yrs}$ \\
\hline $\begin{array}{l}\text { Jacobson et al. } \\
\text { (19) } 2010\end{array}$ & $\begin{array}{l}\text { Bilateral posterior } \\
\text { mandible }\end{array}$ & $\begin{array}{l}\text { Cancer of the } \\
\text { tonsil }\end{array}$ & $\begin{array}{l}\text { Opposing fields of } \\
\text { external beam } \\
\text { RT }\end{array}$ & & $72 / \mathrm{M}$ & 4 yrs \\
\hline $\begin{array}{l}\text { Tursun and } \\
\text { Green (20) } 2017\end{array}$ & $\begin{array}{l}\text { Bilateral posterior } \\
\text { mandible }\end{array}$ & $\begin{array}{l}\text { Base-of the- } \\
\text { tongue } \\
\text { squamous cell } \\
\text { carcinoma }\end{array}$ & 7,000 cGy of radiation & & $72 / \mathrm{M}$ & 13 yrs \\
\hline $\begin{array}{l}\text { Kakarala et al. } \\
\text { (21) } 2011\end{array}$ & Bilateral mandible & $\begin{array}{l}\text { Squamous cell } \\
\text { carcinoma of the } \\
\text { anterior floor of } \\
\text { the mouth }\end{array}$ & RT & $\begin{array}{l}\text { Resection and neck } \\
\text { dissection }\end{array}$ & $36 / F$ & \\
\hline $\begin{array}{l}\text { Horta et al. (22) } \\
2014\end{array}$ & Mandible & & RT & & $41 / F$ & \\
\hline $\begin{array}{l}\text { Kraeima et al. } \\
\text { (23) } 2018\end{array}$ & Left hemimandible & $\begin{array}{l}\text { Squamous cell } \\
\text { carcinoma in the } \\
\text { floor of the mouth } \\
\text { stage pT4N0 }\end{array}$ & RT 56 Gy & $\begin{array}{l}\text { Marginal } \\
\text { mandibular } \\
\text { resection. }\end{array}$ & & 3 months \\
\hline
\end{tabular}




\section{Clinical features}

Tooth extraction, pathologic fracture, life-threatening infection, prolonged hospitalization, and severe chronic pain

\section{Management}

Surgical debridement, 45 dives in hyperbaric oxygen, antibiotic therapy

\section{Any other}

\section{Risk factor}

Submental abscess and an extraoral Abscess was incised, extraction from fistula in the anterior right chin region the left lower first incisor to the right lower canine

\section{Recurrent ORN after 1}

year, suppuration from two fistulas, severe trismus, total lip anesthesia, treated with cultures stem and progenitor cells using bone marrow aspirate
Recurrence occurred twice mandibulectomy was done
Peripheral artery disease, coronary artery disease, arterial hypertension, diabetes mellitus, and a smoking habit

Hypertension, glaucoma, and hyperthyroidism

Exposed bone in the left lower jaw,

Partial resection of the left mandible and immediate reconstruction with fibular graft resistant pain

hyperthyroidism

Left submandibular fistula and pain; Surgical treatment later pathological fracture
ORN with recurrent tumor

Alcohol and tobacco consumption

\section{Bone exposure}

\section{Hyperbaric oxygen, antibiotics, and} local debridements

\section{Marx stage 3 ORN 6 months later; segmental mandibulectomies, with preservation of the native symphysis, and a reconstruction using a single fibular free flap}

Exposed bone in the right mandible with pain, purulent discharge, and severe hypoesthesia in the distribution of the inferior alveolar nerve

\section{ORN}

Antibiotics in addition to chlorhexidine mouth rinses 3 times daily to control the localized infection. The patient underwent hyperbaric oxygen therapy; ultimately surgical resection and fibular graft

\section{Resection and fibular graft}

Wound infection and free flap loss; revision fibular free flap reconstruction was done with VAC

\section{Resection and fibular graft}

Intraoral exposed necrotic bone $\mathrm{HBO}$ treatment; reconstruction with (ORN) and a fractured mandible with iliac graft (30 sessions) an orocutaneous fistula
Chimeric anterolateral thigh flap

Repeat ORN in three weeks; reconstruction with fibular graft 
Table 1. Continued

\begin{tabular}{|c|c|c|c|c|c|c|}
\hline Authors & Site of ORN & $\begin{array}{l}\text { Associated } \\
\text { malignancy with } \\
\text { staging }\end{array}$ & RT cycles & $\begin{array}{l}\text { Any other } \\
\text { concurrent } \\
\text { therapy }\end{array}$ & $\begin{array}{l}\text { Agel } \\
\text { Sex }\end{array}$ & $\begin{array}{l}\text { Duration } \\
\text { after RT }\end{array}$ \\
\hline $\begin{array}{l}\text { Kraeima et al. } \\
\text { (23) } 2018\end{array}$ & Bilateral mandible & $\begin{array}{l}\text { Squamous cell } \\
\text { carcinoma floor } \\
\text { of the mouth }\end{array}$ & RT 56 Gy & $\begin{array}{l}\text { Surgical resection } \\
\text { including a marginal } \\
\text { resection of the } \\
\text { mandible }\end{array}$ & & 11 months \\
\hline $\begin{array}{l}\text { Kraeima et al. } \\
\text { (23) } 2018\end{array}$ & Left mandible & $\begin{array}{l}\text { Squamous cell } \\
\text { carcinoma in the } \\
\text { buccal mucosa of } \\
\text { the left mandible } \\
\text { (pT4N1) }\end{array}$ & RT 66 Gy & $\begin{array}{l}\text { 3D guided surgical } \\
\text { resection, including } \\
\text { neck dissection, } \\
\text { and the defect was } \\
\text { reconstructed with } \\
\text { a free vascularized } \\
\text { fibula flap }\end{array}$ & $84 / \mathrm{M}$ & $\begin{array}{l}20 \\
\text { months }\end{array}$ \\
\hline $\begin{array}{l}\text { Jeyaraj and } \\
\text { Bandyopadhyay } \\
\text { (24) } 2016\end{array}$ & Left mandible & $\begin{array}{l}\text { Carcinoma of the } \\
\text { left tonsil and } \\
\text { faucial pillar and } \\
\text { the left lateral } \\
\text { and posterior } \\
\text { pharyngeal wall }\end{array}$ & RT 76.8 Gy & & $60 / M$ & $\begin{array}{l}10 \\
\text { months; } \\
\text { One } \\
\text { month } \\
\text { after tooth } \\
\text { extraction }\end{array}$ \\
\hline $\begin{array}{l}\text { Badeau and } \\
\text { Deleyiannis (25) } \\
2013\end{array}$ & Left mandible & $\begin{array}{l}\text { Left basaloid } \\
\text { squamous cell } \\
\text { carcinoma with } \\
\text { recurrence }\end{array}$ & RT & Chemotherapy & $59 / \mathrm{M}$ & 3 yrs \\
\hline $\begin{array}{l}\text { Rathy et al. (9) } \\
2013\end{array}$ & Right mandible & $\begin{array}{l}\text { Squamous cell } \\
\text { carcinoma }\end{array}$ & RT & Surgery & $65 / M$ & 4 yrs \\
\hline $\begin{array}{l}\text { Etezadi et al. } \\
\text { (26) } 2013\end{array}$ & Left mandible & $\begin{array}{l}\text { Left tonsillar } \\
\text { squamous cell } \\
\text { carcinoma stage } \\
\text { T4bN3 }\end{array}$ & RT 7,000 cGy & $\begin{array}{l}\text { Radical } \\
\text { tonsillectomy } \\
\text { and modified } \\
\text { neck dissection; } \\
\text { chemotherapy }\end{array}$ & $46 / F$ & \\
\hline $\begin{array}{l}\text { Shimizu et al. } \\
\text { (27) } 2012\end{array}$ & Right mandible & $\begin{array}{l}\text { Nasopharyngeal } \\
\text { cancer }\end{array}$ & $\begin{array}{l}\text { RT } 60 \text { Gy to bilateral } \\
\text { mandible }\end{array}$ & Chemotherapy & $74 / \mathrm{M}$ & $5 \mathrm{yrs}$ \\
\hline $\begin{array}{l}\text { Shimizu et al. } \\
\text { (27) } 2012\end{array}$ & Left mandible & $\begin{array}{l}\text { Nasopharyngeal } \\
\text { cancer }\end{array}$ & $\begin{array}{l}\text { RT } 66 \text { Gy to bilateral } \\
\text { mandible }\end{array}$ & Chemotherapy & $69 / M$ & $3 \mathrm{yrs}$ \\
\hline
\end{tabular}

ORN (14). The most commonly reported treatment in large defects involved mandibular resection followed by free fibular graft and implant supported prosthesis (15). Tursun and Green (20) reported the use of processed allogeneic nerve allograft during surgical treatment for regaining neurosensory function in patients with ORN. Iliac marrow aspirate was used successfully for bone regeneration in one case (16). Kakarala et al. (21) used VAC dressing over free flap muscle to assist the closure of cutaneous defects in ORN. Horta et al. (22) reported a case where the failure of fibular graft was managed using chimeric anterolateral thigh flap and a dural substitute membrane with acceptable results.
Based on the fibroatrophic theory of ORN, a combination of pentoxifylline, tocopherol and clodronate is being tried as medical management in ORN cases refractory to surgery and HBO therapy. This protocol included antibiotic and corticosteroid treatment for one month to control infection followed by pentoxifylline, tocopherol and clodronate for at least six months. The authors reported a resolution rate of around $89 \%(33,34)$. In the present review, Garg et al. (6) was able to achieve good results with a combination of PENTOCLO therapy and sequestrectomy. An additional finding in the study was the incidence of ORN recurrence. As much as $22 \%$ of cases reported the recurrence ranging from 
An intraoral fistula with exposed bone
HBO with soft tissue nasolabial flap; reconstruction using isodose curves
Inability to open his mouth, difficulty in consuming even semisolid food and a persistent dull aching pain in the left side of his lower jaw
Segmental mandibular resection followed by Titanium reconstruction plate
Smoker, microvascular thrombosis, bronchiectasis of lung

Anterior submental draining sinus tract extending to the bone

Antibiotics and hyperbaric oxygen; surgical resection with fibular free flap

Sharp bony projection in the mouth and pus discharge on right cheek

Exposed bone pain, trismus, and intraoral drainage

\section{Sequestrectomy}

HBO; Segmental resection of the affected bone of the mandibular body, bilateral coronoidectomies, and placement of an external pin fixator
Dehiscence of the skin at the incision site with orocutaneous fistula after three months. Reconstruction with fibular flap

\section{ORN of left mandible} occurred 3 yrs later; treated similarly

\section{ORN of right mandible} occurred 2 yrs later; treated similarly
Extraction of left mandibular molar
Surgical resection with fibular osteoseptocutaneous flap chap

tre

Surgical resection with fibular osteoseptocutaneous flap

Cheek skin was stiff, orocutan
fistula, limited mouth opening

Cheek skin was stiff, orocutaneou fistula, limited mouth opening

treated similarly




\section{Ethics}

Peer-review: Externally peer-reviewed.

\section{Authorship Contributions}

Concept: V.A., S.H., Design: V.A., S.H., Data Collection or Processing: V.A., Analysis or Interpretation: V.A., S.H., Literature Search: V.A., Writing: V.A., S.H.

Conflict of Interest: No conflict of interest was declared by the authors.

Financial Disclosure: The authors declared that this study received no financial support.

\section{References}

1. Piccin A, Di Pierro AM, Tagnin M, et al. Healing of a soft tissue wound of the neck and jaw osteoradionecrosis using platelet gel. Regen Med. 2016;11:459-463.

2. Beyzadeoglu M, Dincoglan F, Sager O. Complications of Head and Neck Radiotherapy and Management. In: Beyzadeoglu M, Ozyigit G, Selek U, eds. Radiation Therapy for Head and Neck Cancers A Case-Based Review. Springer-Verlag Berlin, Heidelberg. 2015:221-232.

3. Beech A, Farrier J. Use of the Integra skin regeneration system in an intraoral mandibular defect in osteoradionecrosis. Int J Oral Maxillofac Surg. 2016;45:1159-1161.

4. Rao KA, Shetty SR, Babu SG, Castelino RL. Osteoradionecrosis of the mandible and mastoiditis after radiotherapy for parotid mucoepidermoid carcinoma. Clin Med Res. 2012;10:78-82.

5. Curi MM, Cardoso CL, Benites AFC, Bueno PM. Delayed tongue necrosis simultaneous with bilateral osteoradionecrosis of the jaw secondary to head and neck irradiation. Oral Surg Oral Med Oral Pathol Oral Radiol. 2017; 123:e28-e32.

6. Garg H, Ramaraj PN, Palekar MG, Jain V. Changing trend in management of Osteo radio necrosis of the mandible: $A$ case report. IJADS. 2018;4:271-274.

7. Notani K, Yamazaki Y, Kitada H, Sakakibara N, Fukuda $\mathrm{H}$, Omori K, Nakamura M. Management of mandibular osteoradionecrosis corresponding to the severity of osteoradionecrosis and the method of radiotherapy. Head Neck. 2003;25:181-186.

8. Nadella KR, Kodali RM, Guttikonda LK, Jonnalagadda A. Osteoradionecrosis of the Jaws: Clinico-Therapeutic Management: A Literature Review and Update. J Maxillofac Oral Surg. 2015;14:891-901.

9. Rathy R, Sunil S, Nivia M. Osteoradionecrosis of mandible: Case report with review of literature. Contemp Clin Dent. 2013;4:251-253.

10. Schepers RH, Raghoebar GM, Vissink A, et al. Fully 3-dimensional digitally planned reconstruction of a mandible with a free vascularized fibula and immediate placement of an implant-supported prosthetic construction. Head Neck. 2013;35:E109-E114.
11. Reiffel AJ, Rohde CH, Kutler DI, Spector JA. Sequential second free fibula flap for the reconstruction of metachronous osteoradionecrosis of the mandible. J Craniofac Surg. 2012;23:e90-e91.

12. Poglio G, Grivetto F, Nicolotti M, Arcuri F, Benech A. Management of an exposed mandibular plate after fibula free flap with vacuum-assisted closure system. J Craniofac Surg. 2011;2:905-908.

13. Man QW, Jia J, Liu K, Chen G, Liu B. Secondary reconstruction for mandibular osteoradionecrosis defect with fibula osteomyocutaneous flap flowthrough from radial forearm flap using stereolithographic 3-dimensional printing modeling technology. J Craniofac Surg. 2015;26:e190-e193.

14. Scala M, Gipponi M, Mereu P, et al. Regeneration of mandibular osteoradionecrosis defect with platelet rich plasma gel. In Vivo. 2010;24:889-893.

15. Khatami AH, Toljanic JA, Kleinman A. Mandibular reconstruction with vascularized fibula flap and osseointegrated implants: a clinical report. J Oral Implantol. 2010;36:385-390.

16. Mendonça JJ, Juiz-Lopez P. Regenerative facial reconstruction of terminal stage osteoradionecrosis and other advanced craniofacial diseases with adult cultured stem and progenitor cells. Plast Reconstr Surg. 2010;126:1699-1709.

17. Pautke C, Bauer F, Bissinger O, et al. Tetracycline bone fluorescence: a valuable marker for osteonecrosis characterization and therapy. J Oral Maxillofac Surg. 2010;68:125-129.

18. Le Stanc E, Vilain D, Baglin AC, Tainturier C. Mandibular lesion differential diagnoses in a patient with a previous history of locally advanced head and neck carcinoma. Clin Nucl Med. 2009;34:435-438.

19. Jacobson AS, Buchbinder D, Urken ML. Reconstruction of bilateral osteoradionecrosis of the mandible using a single fibular free flap. Laryngoscope. 2010;120:273-275.

20. Tursun R, Green JM. Immediate Microsurgical Bone and Nerve Reconstruction in the Irradiated Patient: A Case Report. J Oral Maxillofac Surg. 2017;75:1302.e1-1302. e7.

21. Kakarala K, Richmon JD, Lin DT, Deschler DG. Vacuumassisted closure in revision free flap reconstruction. Arch Otolaryngol Head Neck Surg. 2011;137:622-624.

22. Horta R, Costa J, Valença-Filipe R, Amarante JM. ALT chimeric flap associated to a dura mater biomatrix substitute for severe desfigurative mandible osteoradionecrosis and deficient bone consolidation after a free fibula flap. $\mathrm{Br} J$ Oral Maxillofac Surg. 2014;52:670-672.

23. Kraeima J, Steenbakkers RJHM, Spijkervet FKL, Roodenburg JLN, Witjes MJH. Secondary surgical management of osteoradionecrosis using threedimensional isodose curve visualization: a report of three cases. Int J Oral Maxillofac Surg. 2018;47:214-219. 
24. Jeyaraj P, Bandyopadhyay TK. Diagnostic Features and Management Strategy of a Refractory Case of Osteoradionecrosis of the Mandible: Case Report and Review of Literature. J Maxillofac Oral Surg. 2016;15:256267.

25. Badeau AM, Deleyiannis FW-B. CASE REPORT Reconstruction and Characterization of Composite Mandibular Defects Requiring Double Skin Paddle Fibular Free Flaps. Eplasty. 2013;13:e21.

26. Etezadi A, Ferguson $H$, Emam HA, Walker $P$. Multiple remediation of soft tissue reconstruction in osteoradionecrosis of the mandible: a case report. J Oral Maxillofac Surg. 2013;71:e1-e6.

27. Shimizu F, Kato A, Taneda $\mathrm{H}$, et al. Asynchronous osteoradionecrosis of the mandible treated with sequential fibula osteoseptocutaneous flaps: a report of two cases. Ann Plast Surg. 2012;690:283-287.

28. Moon DH, Moon SH, Wang $\mathrm{K}$, et al. Incidence of, and risk factors for, mandibular osteoradionecrosis in patients with oral cavity and oropharynx cancers. Oral Oncol. 2017;72:98-103.

29. Chronopoulos A, Zarra T, Ehrenfeld M, Otto S. Osteoradionecrosis of the jaws: definition, epidemiology, staging and clinical and radiological findings. A concise review. International Dental Journal. 2018;68:22-30.
30. Silvestre-Rangil J, Silvestre FJ. Clinico-therapeutic management of osteoradionecrosis: a literature review and update. Med Oral Patol Oral Cir Bucal. 2011;16:e900-904.

31. Kobayashi W, Teh BG, Kimura H, Kakehata S, Kawaguchi $\mathrm{H}$, Takai Y. Comparison of osteoradionecrosis of the jaw after superselective intra-arterial chemoradiotherapy versus conventional concurrent chemoradiotherapy of oral cancer. J Oral Maxillofac Surg. 2015;73:994-1002.

32. Delanian S, Chatel C, Porcher R, Depondt J, Lefaix $\mathrm{JL}$. Complete restoration of refractory mandibular osteoradionecrosis by prolonged treatment with a pentoxifylline-tocopherol-clodronate combination (PENTOCLO): a phase II trial. Int J Radiat Oncol Biol Phys. 2011;80:832-839.

33. Delanian S, Depondt J, Lefaix JL. Major healing of refractory mandible osteoradionecrosis after treatment combining pentoxifylline and tocopherol: a phase II trial. Head Neck. 2005;27:114-123.

34. Rivero JA, Shamji O, Kolokythas A. Osteoradionecrosis: a review of pathophysiology, prevention and pharmacologic management using pentoxifylline, $\alpha$-tocopherol, and clodronate. Oral Surg Oral Med Oral Pathol Oral Radiol. 2017; 124:464-471. 